\title{
THE INFLUNECE OF 4G/5G POLYMORPHISM OF ACTIVATOR INHIBITOR PLASMINOGEN 1 GENE (PAI-1) ON DEVELOPEMENT DEEP VEIN THROMBOSIS
}

Original scientific paper

\section{Maja Pođanin ${ }^{1}$}

Rifet Terzić

Aldijana Avdić

Amela Jusić

${ }^{1}$ Biology Department, Faculty of Natural Sciences and Mathematics, University of Tuzla, Bosnia and Herzegovina

Received: $12 / 26 / 2019$

Accepted: $3 / 14 / 2020$

\begin{abstract}
Analysis of 4G/5G polymorphisms of PAI-1 gene in interaction with other genetic and external risk factors that induce development of venous thromboembolism can be used for risk assessment for development of venous thromboembolism. Research was conducted on 202 examinees of both genders, older than 18, from north-eastern Bosnia. Experimental group included 100 examinees with diagnosed DVT and 101 examinees who until the sampling procedure did not have diagnosed DVT. In DVT group, following genotype frequencies were determined: 27\% of examinees had a normal genotype $5 \mathrm{G} / 5 \mathrm{G}, 68 \%$ are heterozygotes and $5 \%$ are mutated homozygotes $4 G / 4 G$. In the control group, frequencies of $4 G / 5 G$ polymorphisms of PAI-1 gene were: $42.6 \%$ of examinees have $5 G / 5 G$ genotype, $55.4 \%$ are heterozygotes $4 G / 5 G$ and $2 \%$ are $4 G / 4 G$ genotype. Obtained results support the hypothesis that PAI-1 in interaction with other genetic and external risk factors probably induces the development of venous thromboembolism.
\end{abstract}

Key words: polymorphism 4G/5G, PAI-1 gene, venous thromboembolism;

\footnotetext{
${ }^{1}$ Correspondence to:

Maja Pođanin, Faculty of Natural Sciences and Mathematics, University of Tuzla, Bosnia and Herzegovina
} 


\section{INTRODUCTION}

Venous thromboembolism (VTE) is one of the leading morbidity and mortality factors in developed countries. Disease can manifest itself through venous system obstruction and most often occurs in deep leg veins (Silverstein et al., 1998). Deep venous thrombosis (DVT) is a disease with yearly incidence of one in 2000 in general population. Incidence is the same in men and women, and it increases with age, especially after 40 . Venous thromboembolisms (VTE) occur because of interaction of many different risk factors: acquired, inherited and external factors (De Stefano et al., 1996; Heit and sar., 2000). Risk of occurrence of deep venous thromboembolism rises with the increase of number of risk factors. Nowadays, many risk factors for occurrence of deep venous thrombosis are known, such as: prolonged inactivity, trauma, malicious diseases, age, obesity, estrogene therapy, pregnancy, hyperlipidemia, diabetes, giving a caesarean section birth, confinement up to 6 weeks after giving birth, nephrotic syndrome and other. Most common inherited risk factors are factor $\mathrm{V}$ (FV) mutations and prothrombin 20210A mutations, and elevated homocysteine value. (Alfirević and associates, 2010)

Discovery of polymorphisms in promoter region of PAI-1 gene, caused an increase in interest for PAI1 gene polymorphisms as a genetic risk factor for development of venous thrombosis. 4G/5G insertion/ deletion polymorphism is connected to changes of concentration of PAI 1 in plasma and is $25 \%$ higher in allele mutation carriers than in wild type individuals (Ye et al., 1995; Eriksson et al., Burzota et al., 1998; Margaglione et al., 1998). In addition, according to researches, 4G allele represents an additional risk factor for development of deep venous thrombosis and myocardium infarcts in younger populations in combination with other risk factors (Eriksson et al., 1995; Tsantes et al., 2007).

\section{AIMS OF THE RESEARCH}

Clinical data of 4G/5G PAI-1 gene polymorphisms are inconsistent and it is unknown whether the similar studies were done in our country, so basic aim of this research is to determine the frequency of genotypes $(5 \mathrm{G} / 5 \mathrm{G}, 4 \mathrm{G} / 5 \mathrm{G}$ and $4 \mathrm{G} / 4 \mathrm{G})$ in population of patients with diagnosed venous thromboembolism, and also in the control group of healthy examinees, without known venous thromboembolism risk factors. We also wanted to determine the differences in frequency of $4 \mathrm{G} / 5 \mathrm{G}$ polymorphisms regarding the gender and age of examinees, and to determine the possible connection between $4 \mathrm{G} / 5 \mathrm{G}$ polymorphisms and occurrence of venous thromboembolisms.

\section{MATERIALS AND METHODS}

Research was carried out on 101 healthy examines form Tuzla Canton population who did not have known risks for thrombosis (control group) and 100 examines with diagnosed thromboembolism (DVT group) who were hospitalised in Tuzla University Clinic Center. During the research, ethical standards determined by Helsinki declaration of World Health Organisation (WHO) were honoured. All participants were completely informed about the research protocol, and accepted to participate in the research. All participants were older than 18. Sample of full venous blood was taken from every participant, in the test tube with EDTA anticoagulant (Vacutainer Becton Dickinson, Meylan Cedex, France) on cardiovascular diseases clinic, and samples were preserved at $-20^{\circ} \mathrm{C}$ until they were used in research. DNA isolation and analysis in the researched sample was performed in the Laboratory for scientific work of Biology Department of Faculty of Science of Tuzla University. For DNA isolation was used commercial FlexiGene DNA kit (250) (Qiagen GmbH. Hilden, Germany). Genome DNA was isolated from leucocytes of peripheral blood according to the protocol of FlexiGene DNA Handbook (FlexiGene Handbook Protocol). 
Genome DNA check was performed by electrophoresis on $1.5 \%$ gel. Area of 98bp PAI-1 gene was amplified by polymerase chain reaction (PCR) according to the protocol (Margaglione et al., 1997). PCR product check was performed by electrophoresis on $4 \%$ gel. Electrophoresis lasted 30 minutes with $120 \mathrm{~V}$ voltage in $0.5 \mathrm{X}$ TBE buffer. After the electrophoresis, gel was checked and photographed under the UV light (VWR GenoMini, VWR International, BVBA Leuven). Product of PAI-1 Gene amplification of 98bp was then subjected to simultaneous restrictive digestion with Bs1I restriction enzyme (New England Biolab, The UK). Separation of obtained fragments was performed by electrophoresis on $4 \%$ gel, with $80 \mathrm{~V}$ voltage, lasting 60 minutes.

\section{RESULTS}

In this study we examined the frequency of polymorphism 4G/5G PAI-1 gene in population of examinees with diagnosed venous thromboembolism (DVT) and control group of healthy examinees,
Normal genotype $5 \mathrm{G} / 5 \mathrm{G}$ matches the fragment size of $98 \mathrm{bp}$. Mutated 4G/4G genotypes is characterised by two fragments of 77 and $22 \mathrm{bp}$. Occurrence of all three fragments (98bp, 77p and 22bp) indicate the heterozygote type of 4G/5G PAI-1 polymorphism. For statistical data processing, we used standard statistical package SPSS 15.0 for Windows by SPSS INC. Company and MedCalc 12.4.0.0 (MedCalc Software, Ostend, Belgium). For analysis of distribution of absolute genotype frequencies of individual mutations, and deviation from HardyWeinberg equilibrium, we used $\chi^{2}-$ test of degree of liberty.

without obvious risk factors for this disease. $5 \mathrm{G}$ allele frequency in control group was $70.3 \%, 4 \mathrm{G}$ allele was $29.7 \%$. DVT group has statistically lower frequency of $5 \mathrm{G} / 5 \mathrm{G}$ genotype $\left(\chi^{2}=6.099, p=.021\right)$.

Table 1 Frequencies of genotypes and allele polymorphisms of 4G/5G PAI-1 gene in total sample

\begin{tabular}{|c|c|c|c|c|}
\hline Genotypes & $\begin{array}{l}\text { DVT group } \\
\quad \text { N (\%) }\end{array}$ & $\begin{array}{c}\text { Control group } \\
\mathbf{N}(\%)\end{array}$ & $\begin{array}{c}\text { Prospect ratio } \\
\text { (OR) } \\
(95 \% \mathrm{CI})\end{array}$ & $p$ \\
\hline $\begin{array}{c}\text { Normal Heterozygote } \\
5 \mathrm{G} / 5 \mathrm{G}\end{array}$ & $27(27 \%)$ & $43(42.6 \%)$ & & \\
\hline $\begin{array}{c}\text { Heterozygote } \\
4 \mathrm{G} / 5 \mathrm{G}\end{array}$ & $68(68 \%)$ & $56(55.4 \%)$ & $\begin{array}{c}.498 \\
(.276-.901)\end{array}$ & .021 \\
\hline $\begin{array}{c}\text { Mutated homozygote } \\
4 \mathrm{G} / 4 \mathrm{G}\end{array}$ & $5(5 \%)$ & $2(2 \%)$ & & \\
\hline Allele 5G & $122(61 \%)$ & $142(70.3 \%)$ & $\begin{array}{c}.660 \\
(.436-1.000)\end{array}$ & .050 \\
\hline Allele $4 \mathrm{G}$ & $78(39 \%)$ & $60(29.7 \%)$ & & \\
\hline
\end{tabular}

There is no statistically significant difference in distribution of alleles $5 \mathrm{G}$ and $4 \mathrm{G}$ between examined groups $\left(\chi^{2}=3.853, p=.063\right)$. Prospect ratio (OR) for genotypes, $(4 \mathrm{G} / 4 \mathrm{G}+4 \mathrm{G} / 5 \mathrm{G})$ to $5 \mathrm{G} / 5 \mathrm{G}$, is $.498(.276$ $.901,95 \% \mathrm{CI})$ or value for alleles (4G to $5 \mathrm{G})$ is .660
(.436-1.000, 95\% CI). Hi-Square test proved that there is no significant difference between men and women, in DVT group, related to genotypes $\left(\chi^{2}=3.495, p=\right.$ $.100)$ as well as to alleles $\left(\chi^{2}=1.592, p=.264\right)$. 


\begin{tabular}{ccccc}
\hline Genotypes & $\begin{array}{c}\text { Male } \\
\text { N (\%) }\end{array}$ & $\begin{array}{c}\text { Female } \\
\mathbf{N ~ ( \% )}\end{array}$ & $\begin{array}{c}\text { Prospect ratio OR } \\
(\mathbf{9 5 \%} \mathbf{C})\end{array}$ & $\boldsymbol{p}$ \\
Normal & 16 & 11 & & \\
homozygote 5G/5G & $(36.36 \%)$ & $(19.64 \%)$ & .4278 & \\
Heterozygote & 26 & 42 & $(.173-1.053)$ & .064 \\
4G/5G & $(59.1 \%)$ & $(75 \%)$ & & \\
Mutated & 2 & 3 & & \\
homozygote 4G/4G & $(4.54 \%)$ & $(5.36 \%)$ & .689 & .207 \\
Allele 5G & 58 & 64 & $(.386-1.229)$ & \\
& $(65.9 \%)$ & $(57.1 \%)$ & & \\
Allele 4G & 30 & 48 & & \\
\hline
\end{tabular}

Prospect ratio (OR), for genotypes, between men and $\left.{ }^{2}=1.622, p=.285\right)$, and neither in the allele frequency $\left(\chi^{2}\right.$ women, in this group was $.427(.173-1.053,95 \% \mathrm{CI},=.850, p=.444)$. Prospect ratio (OR) value for genotypes and for alleles $.689(.386-1.229,95 \%$ CI). There was was $1.681(.753-3.753,95 \%$ CI), and for alleles 1.338 no statistically significant difference between genotype $(.719-2.491,95 \% \mathrm{CI})$.

frequencies, between men and women in control group $(\chi$

Table 3 Frequency of alleles and genotypes for polymorphism of 4G/5G PAI-1 gene in relation to gender in control group

\begin{tabular}{lcccc}
\hline \multicolumn{1}{c}{ Genotypes } & $\begin{array}{c}\text { Male } \\
\text { N (\%) }\end{array}$ & $\begin{array}{c}\text { Female } \\
\mathbf{N ~ ( \% )}\end{array}$ & $\begin{array}{c}\text { Prospect ratio OR } \\
(\mathbf{9 5 \%} \mathbf{C})\end{array}$ & $\boldsymbol{p}$ \\
Normal homozygote & 22 & 21 & & \\
$5 \mathrm{G} / 5 \mathrm{G}$ & $(37.29 \%)$ & $(50 \%)$ & 1,681 & .204 \\
& 36 & 20 & $(.753-3.75)$ & \\
Heterozygote & $(61.02 \%)$ & $(47.62 \%)$ & & \\
4G/5G & 1 & 1 & & .357 \\
Mutated homozygote & $(1.69 \%)$ & $(2.38 \%)$ & & \\
4G/4G & 80 & 62 & 1,338 & \\
\hline Allele 5G & $(67.8 \%)$ & $(73.8 \%)$ & $(.719-2.491)$ & \\
& 38 & 22 & & \\
Allele 4G & $(32.2 \%)$ & $(26.2 \%)$ & & \\
\hline
\end{tabular}

We have determined that there is no statistically .893). In contrast to this, in women of DVT group, significant difference in distribution frequencies of there is a statistically bigger share of $4 \mathrm{G} / 5 \mathrm{G}$ genotype genotypes between males in DVT and control group $\left(\chi^{2}=10.058, p=.003\right)$ as well as of allele $4 \mathrm{G}\left(\chi^{2}=\right.$ $\left(\chi^{2}=.009, p=.913\right)$ as well as alleles $\left(\chi^{2}=.081, \mathrm{p}=5.807, p=.024\right)$.

Table 4 Frequency of alleles and genotypes for polymorphism of 4G/5G PAI-1 gene in relation to gender in total sample

\begin{tabular}{|c|c|c|c|c|c|c|c|c|}
\hline \multirow[t]{2}{*}{ Genotypes } & \multicolumn{2}{|c|}{ DVT Group } & \multicolumn{2}{|c|}{ Control Group } & \multicolumn{2}{|c|}{$\begin{array}{c}\text { Prospect Ratio (OR) } \\
(95 \% \mathrm{CI})\end{array}$} & \multicolumn{2}{|c|}{$p$} \\
\hline & $\begin{array}{l}\text { Male } \\
\mathrm{N}(\%)\end{array}$ & $\begin{array}{l}\text { Female } \\
\mathrm{N}(\%)\end{array}$ & $\begin{array}{l}\text { Male } \\
\mathrm{N}(\%)\end{array}$ & $\begin{array}{l}\text { Female } \\
\mathrm{N}(\%)\end{array}$ & Male & Female & Male & Female \\
\hline $\begin{array}{c}\text { Normal } \\
\text { homozygote } \\
5 \mathrm{G} / 5 \mathrm{G}\end{array}$ & $\begin{array}{c}16 \\
(36.36 \%)\end{array}$ & $\begin{array}{c}11 \\
(19.64 \%)\end{array}$ & $\begin{array}{c}22 \\
(37.29 \%)\end{array}$ & $\begin{array}{c}21 \\
(50 \%)\end{array}$ & & & & \\
\hline $\begin{array}{l}\text { Heterozygote } \\
4 \mathrm{G} / 5 \mathrm{G}\end{array}$ & $\begin{array}{c}26 \\
(59.1 \%)\end{array}$ & $\begin{array}{c}42 \\
(75 \%)\end{array}$ & $\begin{array}{c}36 \\
(61.02 \%)\end{array}$ & $\begin{array}{c}20 \\
(47.62 \%)\end{array}$ & $\begin{array}{c}1.040 \\
(.463-2.3385)\end{array}$ & $\begin{array}{c}4.090 \\
(1.6721- \\
10.0087)\end{array}$ & .923 & .002 \\
\hline $\begin{array}{c}\text { Mutated } \\
\text { homozygote } \\
4 \mathrm{G} / 4 \mathrm{G}\end{array}$ & $\begin{array}{c}2 \\
(4.54 \%) \\
\end{array}$ & $\begin{array}{c}3 \\
(5.36 \%) \\
\end{array}$ & $\begin{array}{c}1 \\
(1.69 \%)\end{array}$ & $\begin{array}{c}1 \\
(2.38 \%) \\
\end{array}$ & & & & \\
\hline Allele $5 \mathrm{G}$ & $\begin{array}{c}58 \\
(65.9 \%)\end{array}$ & $\begin{array}{c}64 \\
(57.1 \%)\end{array}$ & $\begin{array}{c}80 \\
(67.8 \%)\end{array}$ & $\begin{array}{c}62 \\
(73.8 \%)\end{array}$ & 1.088 & 2.113 & & \\
\hline Allele 4G & $\begin{array}{c}30 \\
(34.2 \%)\end{array}$ & $\begin{array}{c}48 \\
(42.9 \%)\end{array}$ & $\begin{array}{c}38 \\
(32.2 \%)\end{array}$ & $\begin{array}{c}22 \\
(26.2 \%)\end{array}$ & $(.606-1.9566)$ & $\begin{array}{l}(1.1442- \\
3.9045)\end{array}$ & .775 & .016 \\
\hline
\end{tabular}


Prospect ratio (OR) for genotypes in male population was $1.040(.463-2.338,95 \% \mathrm{CI})$, and women 4,090 (1.672-10.008, 95\% CI). Prospect ratio (OR) for allele in male population was $1,088(0,606-1,956,95 \% \mathrm{CI})$, and women population was $2.113(1.144-3.904,95 \%$
CI). There was no significant difference in relation to age in observed groups in relation to genotypes $\left(\chi^{2}=\right.$ $4.778, p=.062 ; \chi^{2}=.351, p=.712 ; \chi^{2}=2.725, p=$ $.171)$, and neither in relation to alleles $\left(\chi^{2}=2.53, p=\right.$ $\left..175 ; \chi^{2}=.256, p=.733 ; \chi^{2}=1,929, p=.228\right)$.

Table 5 Frequency of alleles and genotypes for polymorphism of $4 G / 5 G$ PAI-1 gene in relation to age

\begin{tabular}{|c|c|c|c|c|c|}
\hline Age & Genotype & $\begin{array}{c}\text { DVT group N } \\
(\%)\end{array}$ & $\begin{array}{c}\text { Control group } \mathrm{N} \\
(\%)\end{array}$ & OR/95\%CI)* & $p$ \\
\hline \multirow[t]{3}{*}{$<40$} & Normal genotype/5G & $2(13.33 \%)$ & $16(45.71 \%)$ & \multirow{3}{*}{$\begin{array}{c}5.473 \\
(1.071-27.951)\end{array}$} & \multirow{3}{*}{.041} \\
\hline & Heterozygote $4 \mathrm{G} / 5 \mathrm{G}$ & $13(86.67 \%)$ & $19(54.29 \%)$ & & \\
\hline & Homozygote 4G/4G & $0(0 \%)$ & $0(0 \%)$ & & \\
\hline \multirow[t]{3}{*}{$40-59$} & Normal genotype $5 \mathrm{G} / 5 \mathrm{G}$ & $19(36.54 \%)$ & $15(42.86 \%)$ & \multirow{3}{*}{$\begin{array}{c}1,302 \\
(.542-3.126)\end{array}$} & \multirow{3}{*}{.554} \\
\hline & Heterozygote $4 \mathrm{G} / 5 \mathrm{G}$ & $31(59.61 \%)$ & $19(54.28 \%)$ & & \\
\hline & Homozygote 4G/4G & $2(3.85 \%)$ & $1(2.86 \%)$ & & \\
\hline \multirow{3}{*}{$\begin{array}{l}60 \text { and } \\
\text { more }\end{array}$} & Normal genotype $5 \mathrm{G} / 5 \mathrm{G}$ & $6(18.18 \%)$ & $11(36.66 \%)$ & \multirow{3}{*}{$\begin{array}{c}2,605 \\
(.820-8.26)\end{array}$} & \multirow{3}{*}{.104} \\
\hline & Heterozygote $4 \mathrm{G} / 5 \mathrm{G}$ & $24(72.73 \%)$ & $18(60 \%)$ & & \\
\hline & Homozygote 4G/4G & $3(9.09 \%)$ & $1(3.34 \%)$ & & \\
\hline \multirow[t]{2}{*}{$<40$} & Allele $5 \mathrm{G}$ & $17(56.7 \%)$ & $51(72.8 \%)$ & \multirow{2}{*}{$\begin{array}{c}2.052 \\
(.839-5.017)\end{array}$} & \multirow{2}{*}{.114} \\
\hline & Allele 4G & $13(43.3 \%)$ & $19(27.2 \%)$ & & \\
\hline \multirow[t]{2}{*}{$40-59$} & Allele $5 \mathrm{G}$ & $69(66.3 \%)$ & $49(70 \%)$ & \multirow{2}{*}{$\begin{array}{c}1,183 \\
(.615-2.274)\end{array}$} & \multirow{2}{*}{.613} \\
\hline & Allele 4G & $35(33.7) \%$ & $21(30 \%)$ & & \\
\hline \multirow[t]{2}{*}{$\begin{array}{l}60 \text { and } \\
\text { more }\end{array}$} & Allele 5G & $36(55 \%)$ & $40(66.7 \%)$ & \multirow{2}{*}{$\begin{array}{c}1.6667 \\
(.8087-3.4347)\end{array}$} & \multirow{2}{*}{.1662} \\
\hline & Allele 4G & $30(45 \%)$ & $20(33.3 \%)$ & & \\
\hline
\end{tabular}

\section{DISCUSSION}

In our research we determined the $4 \mathrm{G}$ allele frequency in DVT group of 39\%, and in control group $29.7 \%$, 5\% are homozygote mutation carriers 4G/5G PAI-1 in DVT group and $2 \%$ in control group. Heterozygote had a frequency of $68 \%$ in DVT group and 55.4\% in control group. In relation to frequency of $4 \mathrm{G}$ allele, our data do not deviate from data from literature. Similarly, frequencies of $5 \mathrm{G} / 5 \mathrm{G}$ and $4 \mathrm{G} / 5 \mathrm{G}$ genotypes, obtained in this research, are close to those in literature. In our research there is a significant difference in distribution frequency of $5 \mathrm{G} / 5 \mathrm{G}$ genotype between the examined groups $(p=.021)$. Frequency of homozygote $4 \mathrm{G} / 4 \mathrm{G}$ mutation carriers is significantly lower in both groups (DVT 5\%, control 2\%) than in results of similar studies. In Alfirević et al., (2010) study on 100 DVT patients and 100 healthy examines, frequency of homozygote $4 \mathrm{G} / 4 \mathrm{G}$ mutation carriers in DVT group was $31 \%$ and $32 \%$ in control group. There were no significantly different results in distribution frequencies of individual genotypes between DVT and control groups. Several different studies showed that $4 \mathrm{G} / 5 \mathrm{G}$ polymorphism of PAI-1 gene is a risk factor development of venous thromboembolism. Grubić et al., (1996) examined the association of PAI-1 polymorphism and DVZ in studies of couples carried out on 83 patients with diagnosed DVT and 50 healthy examinees. In patients with VT, the highest level of PAI-1 in plasma was found in individuals with $4 \mathrm{G} / 4 \mathrm{G}$ genotype, and the lowest level was in individuals with $5 \mathrm{G} / 5 \mathrm{G}$ polymorphism. In contrast to this study, Sartori et al., (1996) had a similar research with 70 DVT patients and 100 healthy examinees, this study determined that prevalence of $5 \mathrm{G}$ homozygote carriers was significantly lower (10\%) than in control group (26\%) $(p=.009)$. Ridker et al., (1997), in study carried out on sample of 14916 males did not determine the differences in allele frequency between the VT patients and healthy individuals. 
Connection between $4 \mathrm{G} / 5 \mathrm{G}$ polymorphisms of PAI-1 gene in Turkish population was researched by Akar et al., (2000). This study of couples observed 127 DVT patients and 113 healthy examinees that constituted the control group. Authors did not find any correlation between PAI-1 genotype and VT. It seems that $4 \mathrm{G}$ allele increases the risk for VT in presence of simultaneous inherited polymorphism for factor $\mathrm{V}$ Leiden with prospect ratio of $5.5 \%(95 \%$ reliability interval $[\mathrm{Cl}] 1.7$ 6.3). Similar studies were carried out by Seguì et al., (2000). They researched 4G/5G polymorphisms of PAI1 gene in patients with additional genetic risk factors for development of thromboembolism. Research was carried out on group of 190 patients with diagnosed DVT and 152 control examinees. In this study, there was no difference in distribution of $4 \mathrm{G} / 5 \mathrm{G}$ alleles between the DVT patients and control group. However, presence of $4 \mathrm{G}$ allele significantly increases the risk of development of thrombosis in patients with other thrombophilic defects (OR 8.14; 95\% Cl 2.3-28.7). Same study also proved that PAI-1 antigen and values of his activity are higher in patients than in control group and that $4 \mathrm{~g}$ allele is connected to increased values of PAI- 1 plasma in patients. No correlation was found between $4 \mathrm{G} / 5 \mathrm{G}$ polymorphisms with level of PAI-1 in control group. We also did not find statistically significant differences in frequency of $4 \mathrm{G} / 5 \mathrm{G}$ polymorphisms between male examinees in distribution of genotypes and alleles between the DVT patients and control group examinees, which match the data from literature. In female examinees, we determined statistically significantly higher share of $4 \mathrm{G} / 5 \mathrm{G}$ genotype in patients with DVT $(\chi$ $\left.{ }^{2}=10.058, p=.003\right)$ as well as alleles $4 \mathrm{G}\left(\chi^{2}=5.807, p=\right.$ .024) compared to control group, which can be explained by small sample size. We also examined the differences in frequency of $4 \mathrm{G} / 5 \mathrm{G}$ polymorphisms in relation to age between the examined groups. There was no significant difference in genotype and allele distribution between DVT patients and healthy examinees from control group. Relative risk for development of thrombosis for $4 \mathrm{G} / 4 \mathrm{G}$ and $4 \mathrm{G} / 5 \mathrm{G}$ genotype carriers in DVT patients in relation to control group examinees with age under 40 is 5.47 (95\% $\mathrm{Cl} 1.071-27.951)$. According to former researches,
4G allele in combination with other risk factors, in younger ages represents and additional risk factor for development of DVT and myocardial infarctions (Eriksson et al., 1995; Tsantes et al., 2005). Our results support the hypotheses that PAI-1 in interaction with other genetic and external factors probably induces the development of venous thromboembolism.

\section{CONCLUSIONS}

Based on the obtained values of frequency of polymorphous 4G allele of polymorphism of PAI-1 in the sample from Tuzla Canton area, we did not confirm the connection between this polymorphism and occurrence of venous thromboembolism. This polymorphism can not be considered as a main risk factor for VT, and its influence on VT should be researched together with other genetic and acquired VT risk factors.

\section{REFERENCES}

Alfirević Z., Simundić A. M., Nora Nikolac, Sobocan N., Alfirević I., Stefanović M., Vucicević Z., \& Topić E. (2010). Frequency of factor II G20210A, factor V Leiden, MTHFR C677T and PAI-1 5G/4G polymorphism in patients with venous thromboembolism, Croatian case control study. Biochemia Medica, 20 (2):229-35.

Akar, N., Yilmaz E., Akar E., Avcu F., Yalcin A., \& Cin S. (2000). Effect of plasminogen activator inhibitor-1 $4 \mathrm{G} / 5 \mathrm{G}$ polymorphism in Turkish deep vein thrombotic patients with and without FV1691 G-A. Thromb Res, 97, 227-30.

Burzotta, F. , DiCastelnuovo A., Amore A., et al. (1998). 4G/5G promoter PAI-1 gene polymorphism is associated with plasmatic PAI-1 activity in Italians: a model of gene-environment interaction. Thromb Haemost, 79, 354-8.

De Stefano V., Finazzi G., \& Mannucci P. M. (1996). Inherited thrombophilia: pathogenesis, clinical syndromes, and management. Blood, 87, 3531-44.

Eriksson, P., Kallin B., van’t Hooft F. M., Bavenholm P., \& Hamsten A. (1995). Allele-specific increase in basal transcription of the plasminogen activator inhibitor-1 gene is associated with myocardial infarction. Proc Natl Acad Sci US A, 92, 1851-5.

Grubić, N., Stegnar M., Peternel P., Kaider A., R. \& Binder B. (1996). A novel $\mathrm{G} / \mathrm{A}$ and the $4 \mathrm{G} / 5 \mathrm{G}$ polymorphism within the promoter of the plasminogen activator inhibitor-1 gene in patients with deep vein thrombosis. Thromb Res., 84, 431-43. 
Heit J. A., Silverstein M. D., Mohr D. N., Tanya M., Petterson M. S., O'Fallon W.M., \& Melton L. J. (2000). Risk factors for deep vein thrombosis and pulmonary embolism a population-based casecontrol study. Arch Intern Med,160, 809-15.

Isordia-Salas I., Leaños-Miranda A., M Sainz I., Reyes-Maldonado E., \& Borrayo-Sánchez G. (2009). Association of the Plasminogen Activator Inhibitor-1 Gene 4G/5G Polymorphism With ST Elevation Acute Myocardial Infarction in Young Patients. Rev Esp Cardiol., 62(04), 365-72.

Junker, R. , Nabavi D. G., WolffE., et al. (1998). Plasminogen activator inhibitor-1 4G/4G-genotype is associated with cerebral sinus thrombosis in factor V Leiden carriers. Thromb Haemost, 80, 706-707.

Margaglione M., Grandone E., Cappucci G., Colaizzo D., Giuliani N., Vecchione G., d'Addedda M., \& Di Minno G. (1997). An alternative method for PAI-1 promoter polymorphism (4G/5G) typing. Thromb Haemost, 77, 605-6.

Margaglione,M., GrandoneE., VecchioneG., etal.(1997). Plasminogen activator inhibitor-1 (PAI-1) antigen plasma levels in subjects attending a metabolic ward: relation to polymorphisms of PAI-1 and angiotensin converting enzyme (ACE) genes. Arterioscler Thromb Vasc Biol., 17, 2082-7.

Ridker, P. M., Hennekens C. H., Lindpaintner K., Stampfer M. J., \& Miletich J. P. (1997). Arterial and venous thrombosis is not associated with the $4 \mathrm{G} / 5 \mathrm{G}$ polymorphism in the promoter of the plasminogen activator inhibitor gene in a large cohort of US men. Circulation, 95, 59-62.

Sartori, M. T. ,Wiman B., Vettore S., Dazzi F., Girolami A., \& Patrassi G. M. (1998). 4G/5G polymorphism of PAI-1 gene promoter and fibrinolytic capacity in patients with deep vein thrombosis. Thromb Haemost., 80, 956-60.

Seguí, R. , Estellés A., Mira Y., et al. (2000). PAI-1 promoter 4G/5G genotype as an additional risk factor for venous thrombosis in subjects with genetic thrombophilic defects. Br J Haematol., 111, $122-8$.
Silverstein M., Heit J., Mohr D., Petterson T., O’Fallon W., \& Melton L. (1998). Trends in the incidence of deep vein thrombosis and pulmonary embolism: a 25-year population-based, cohort study. Arch Intern Med,158, 585-93.

Stegnar, M. , Uhrin P., Peternel P., et al. (1998). The 4G/5G sequence polymorphism in the promoter of plasminogen activator inhibitor-1 (PAI-1) gene: relationship to plasma PAI-1 level in venous thromboembolism. Thromb Haemost., 79, 975-9.

Tassies, D. , Espinosa G., Muñoz-Rodriguez F. J., et al. (2000). The $4 \mathrm{G} / 5 \mathrm{G}$ polymorphism of the type 1 plasminogen activator inhibitor gene and thrombosis in patients with antiphospholipid syndrome. Arthritis Rheum., 43, 2349-58.

Tsantes A. E., Nikolopoulos G. K., Bagos P. G., Rapti E., Mantzios G., Kapsimali V.,\& Travlou A. (2007). Association between the plasminogen activator inhibitor-1 4G/5G polymorphism and venous thrombosis, A meta analysis. Thromb Haemost, 97:90713.

Wheeler H. B., Anderson F. A. Jr, Cardullo P. A., Patwardhan N. A., Jian-Ming L., \& Cutler B. S. (1982). Suspected deep vein thrombosis. Management by impedance plethysmography. Arch Surg, 117, 1206-9.

Ye, S. , Green F. R., Scarabin P. Y., et al. (1995). The 4G/5G genetic polymorphisms in the promoter of the plasminogen activator inhibitor-1 (PAI-1) gene is associated with differences in plasma PAI-1 activity but not with risk of myocardial infarction in the ECTIM study. Thromb Haemost., 74, 837-41.

Zöller, B. , García de Frutos P., \& Dahlbäck B. (1998). A common 4G allele in the promoter of the plasminogen activator inhibitor-1 (PAI-1) gene as a risk factor for pulmonary embolism and arterial thrombosis in hereditary protein S deficiency. Thromb Haemost., $79,802-7$. 